\title{
Dynamics of professional burnout - a comparative analysis considering the selected sectors in Poland, part II
}

Prof. Stanisław A. Witkowski Copper Region Vocational College (UZZM) Lubin

Magdalena Ślazyk-Sobol, Ph.D. University of Wrocław, Institute of Psychology

\section{Introduction}

The purpose of this article is to present the second part of the results of the empirical studies on the issues of a professional burnout among representatives of the major occupational groups in Poland. (Witkowski, Ślazyk - Sobol, 2012). The present article is on the dynamics of the phenomenon of burnout diagnosed upon nine months after the first test in the group of civil servants, armed forces officers, teachers, health care and trade / services staff. The second part of the study is also based on the organisational concept of burnout developed by Maslach and Leiter $(2008,2010,2011)$ the main assumption of which refers to universality of the syndrome treated as the opposite of involvement in professional work. The conducted re-test assessed the role of organisational factors in the process of development of particular symptoms of burnout. The dependency models for each of the tested sectors were developed.

Dynamics of professional burnout 


\section{Methodology of the research}

In the consecutive stage of the research the authors wished to answered the following research questions:

1. Which of the tested organisational factors were predictors of the phenomenon and its components at the re-test in reference to various professional groups?

2. How dynamic is the phenomenon of occupational burnout (P1 - P2) defined as a significant variance between the first (I) measurement of the level of professional burnout and its second (II) measurement - after nine months? Based on the literature, the following research hypothesis was formulated:

H: Professional burnout is a dynamic phenomenon with varying intensity of symptoms (by: Cherniss, 1992, 1993, 1995, Golembiewski, Scherb, Boudreau, 1993a, Golembiewski et al., 1993b).

Table 1. Operationalisation of the variables used in the re-test study

\begin{tabular}{l|l}
\hline Emotional exhaustion & $\begin{array}{l}\text { Dependent variable, a component of } \\
\text { professional burnout }\end{array}$ \\
\hline Cynicism & as above. \\
\hline A sense of personal achievements & as above. \\
\hline $\begin{array}{l}\text { Perception of organisational climate and its } \\
\text { components }\end{array}$ & Independent variable \\
\hline $\begin{array}{l}\text { General scale of organisational climate, perception } \\
\text { of colleagues, superiors, corporate information and } \\
\text { communication flow, representing staff interests, } \\
\text { opportunities of development and professional } \\
\text { career. }\end{array}$ & $\begin{array}{l}\text { Independent variables, components of the } \\
\text { organisational climate, main predictors of } \\
\text { measured burn - out }\end{array}$ \\
\hline
\end{tabular}

Source: own study

Adequately to the first diagnosis of the dependent variable (professional burnout), the Burnout Inventory Questionnaire by Maslach, General Survey version, designed to examine representatives of professional groups (the licence purchased on the grounds of the Agreement No. TA-207, MBI-GS, Polish by Mind Garden) was applied. The Questionnaire for examination of organisational climate by L. Rosenstiel (with its Polish adaptation by S.A. Witkowski and P. Augustynowicz, 1997) was applied to measure the perception of organisational 
climate. It was recognised that, within the interval of nine months, staff feelings and opinions on the place of their employment may be subject to the largest changes, therefore the tool was used again.

The second stage of the research was conducted in 2011-2012at the territory of the following provinces: Lower Silesia (dolnośląski), Cuyavia - Pomerania (kujawskopomorski), Lesser Poland (małoposlki) and Subcarpathian (podkarpacki). It was attended by 116 people representing $22,84 \%$ of the sample. The main reasons which caused the tested group to be reduced in number were as follows: losing contact with the previously tested people, their failure to appear at the meeting or refusal to take part in the next stage of the research. The largest professional group at the re-test was represented by armed forces officers $(36,03 \%$ of all the tested people) and health care staff $(24,32 \%)$. Services and trade accounted for $14,41 \%$, education - $13,51 \%$ and public administration - $11,71 \%$.

The method of neural networks based on the optimisation of structures with the application of genetic algorithms (STATISTICA Data Mining Programme) was re-used for the analysis of the results. The performed calculations revealed cause-effect dependencies of the analysed variables with regard to interactions taking place between and among the independent variables and their impact on the dependent variables (also interactive with each other). The most relevant criterion related to the application of the specified method referred to its high efficiency connected with the reduction of problems on non-linearity (which turned out to be important for the analysis of so many variables). Dependency models are reflected at $95 \%$ in the general population. In addition, population models were obtained through the application of cross-validation methods.

\section{Research results}

A Student's t-distribution test for dependent samples was performed at the retest of the research in order to diagnose the dynamics of professional burnout and the variability of its components together with the perception of organisational climate. All the statistically significant differences are marked in red.

Analysing the dynamics of changes in the scope of measuring the variable: professional burnout, treated as the results obtained in the MBI-GS Questionnaire, its should be noted that there are significant changes between the scales: cynicism and at the level of burnout treated as the total result of the three scales. At the re-test, cynicism significantly increased being the second component of burnout ( $M=5,60$ at the first measurement, $M=11,90$ - at the second one) and an average level of total burnout $(\mathrm{M}=40,70$ at the first measurement, 
$M=49,30$ - at the second one) increased as well. Therefore, the presented results demonstrate the dynamics of the process of "burnout" demonstrated in a significant increase in cynicism of the tested people, which - according to Maslach and Leiter - means "taking a distanced, cool attitude towards work and colleagues" (Maslach, Leiter, 2011, p. 35). People who are diagnosed with the rise of this component of burnout, minimise their commitment to performed work, become indifferent to the surrounding world. They try to withdraw from interpersonal relationships so that - through behaving in this manner - secure themselves against any disappointments or failures. They demonstrate their negative attitude to professional tasks, colleagues and superiors.

As suggested by the researchers of the phenomenon (Maslach, Leiter, 2008, 2010, 2011), severe emotional exhaustion is the first stage of burnout with a significant increase of cynicism in professional relationships being yet another alarming symptom.

Table. 2. Student's t-distribution statistics for dependent samples for two repeated measurements of professional burnout and organisational climate (course: own study)

\begin{tabular}{|c|c|c|c|c|c|}
\hline Variables & Mean & SD & $\mathbf{t}$ & df & p \\
\hline Emotional exhaustion & 11,23 & 6,73 & \multirow{2}{*}{$-1,788$} & \multirow{2}{*}{110} & \multirow{2}{*}{0,076} \\
\hline Emotional exhaustion - retest & 12,48 & 7,34 & & & \\
\hline Cynicism & 5,60 & 5,47 & \multirow{2}{*}{$-10,247$} & \multirow{2}{*}{110} & \multirow{2}{*}{$<0,01$} \\
\hline Cynicism - retest & 11,90 & 6,28 & & & \\
\hline A sense of achievements & 23,86 & 6,31 & \multirow{2}{*}{$-1,716$} & \multirow{2}{*}{110} & \multirow{2}{*}{0,089} \\
\hline A sense of achievements - retest & 25,08 & 5,97 & & & \\
\hline Burnout - global effect & 40,70 & 12,37 & \multirow{2}{*}{$-6,921$} & \multirow{2}{*}{110} & \multirow{2}{*}{$<0,01$} \\
\hline Burnout - global effect - retest & 49,30 & 12,01 & & & \\
\hline $\begin{array}{l}\text { Organizational climate - } \\
\text { Superiors }\end{array}$ & 42,07 & 11,69 & \multirow{2}{*}{2,282} & \multirow{2}{*}{107} & \multirow{2}{*}{0,024} \\
\hline $\begin{array}{l}\text { Organizational climate - } \\
\text { Superiors - retest }\end{array}$ & 39,05 & 13,51 & & & \\
\hline
\end{tabular}

Source: own study

91 
The above table also shows the results of double measuring of the variable: organisational climate. The only statistically significant differences referring to the re-measurement concern the sub-scales: perception of superiors. The tested people evaluated their superiors more negatively in the second test referring to their style of team management, task delegation and accounting for work effects. However, the overall assessment of organisational climate did not turn out to be significantly different (in statistically terms) from the perception of climate at the first test.

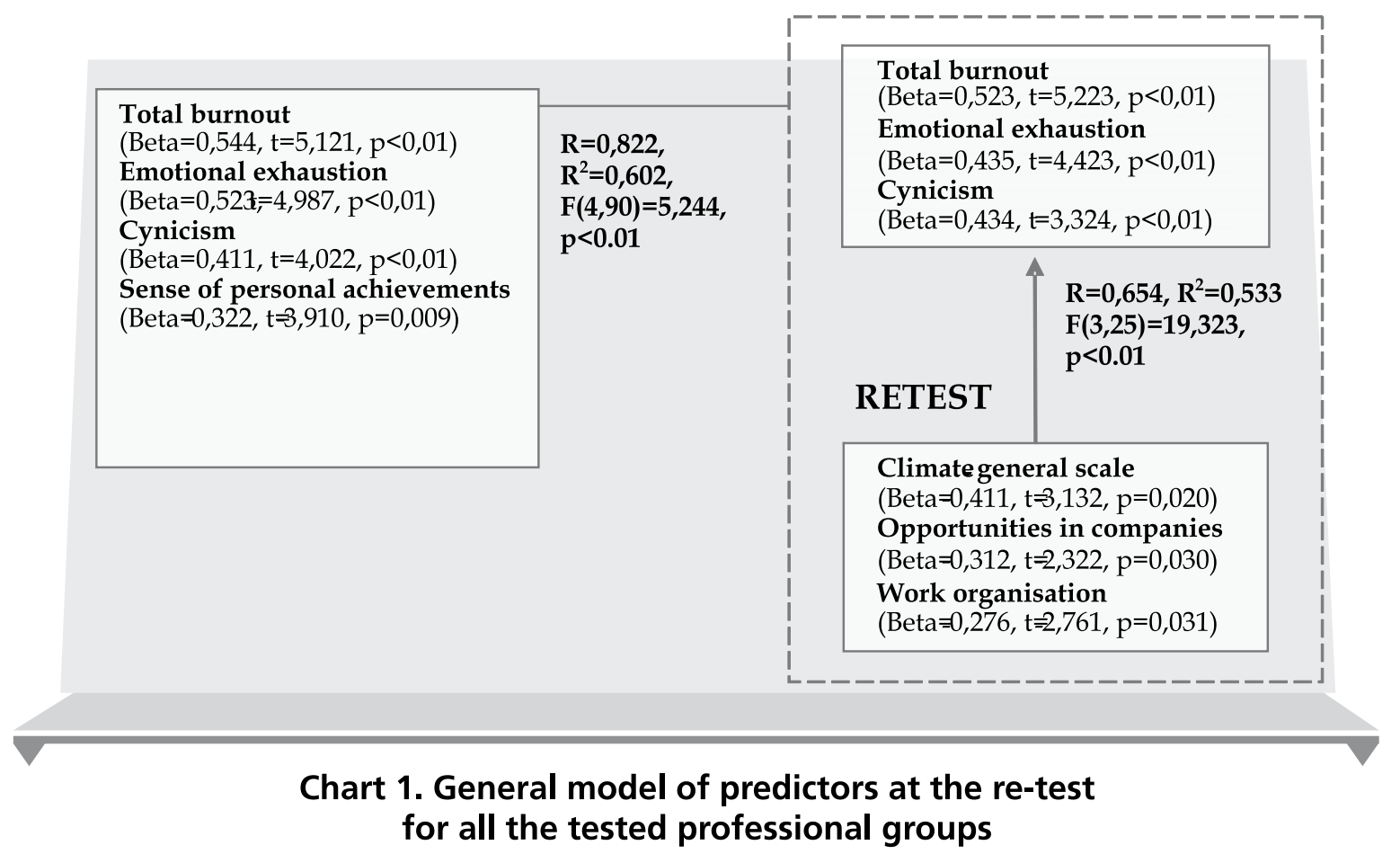

Source: own study

Thought should be given to any possible links between the growing attitude of cynicism in relation to professional work and at the same time more negative and harsher assessments of superiors. Maybe relationships with managers significantly deteriorated over the period of nine months or maybe the result is due to the deepening spiral of further symptoms of burnout which significantly got intensified.

In order to answer the research questions regarding the groups of predictors affecting thelevel of professional burnout of people employed in particular sectors 
at the re-test, once again the cause-effect dependency models were constructed using the method of neutral networks based on the optimisation of structures with the application of genetic algorithms (with the use of STATISTICA Data Mining Programme). The general model which applies to all the tested sectors is presented below.

The general perception of organisational climate referring to job satisfaction, working conditions, social relationships in organisations is the variable which mostly determines professional burnout within long-term perspective (re-test). As shown at the graph, at the re-test the predictors with their strength of 0,654 affect the level of burnout and explain as much as 53\% of its variability. However, it should be noted that the level of the dependent variables (burnout defined as based on three components) in the perspective of the interval of nine months, is mostly affected by the results at the scales of burnout $(R=0,822, F(4,90)=$ $5,244, \mathrm{P}<0,01)$ obtained in the first test. It means that experiencing particular symptoms of burnout in the past by people employed in all the sectors intensely contributes to the occurrence and deepening of this phenomenon at the re-test. The tested people who experienced first symptoms of burnout became more cynical and "burned-out” professionally at the re-test.

Below the graph of dependencies for civil servants was presented.

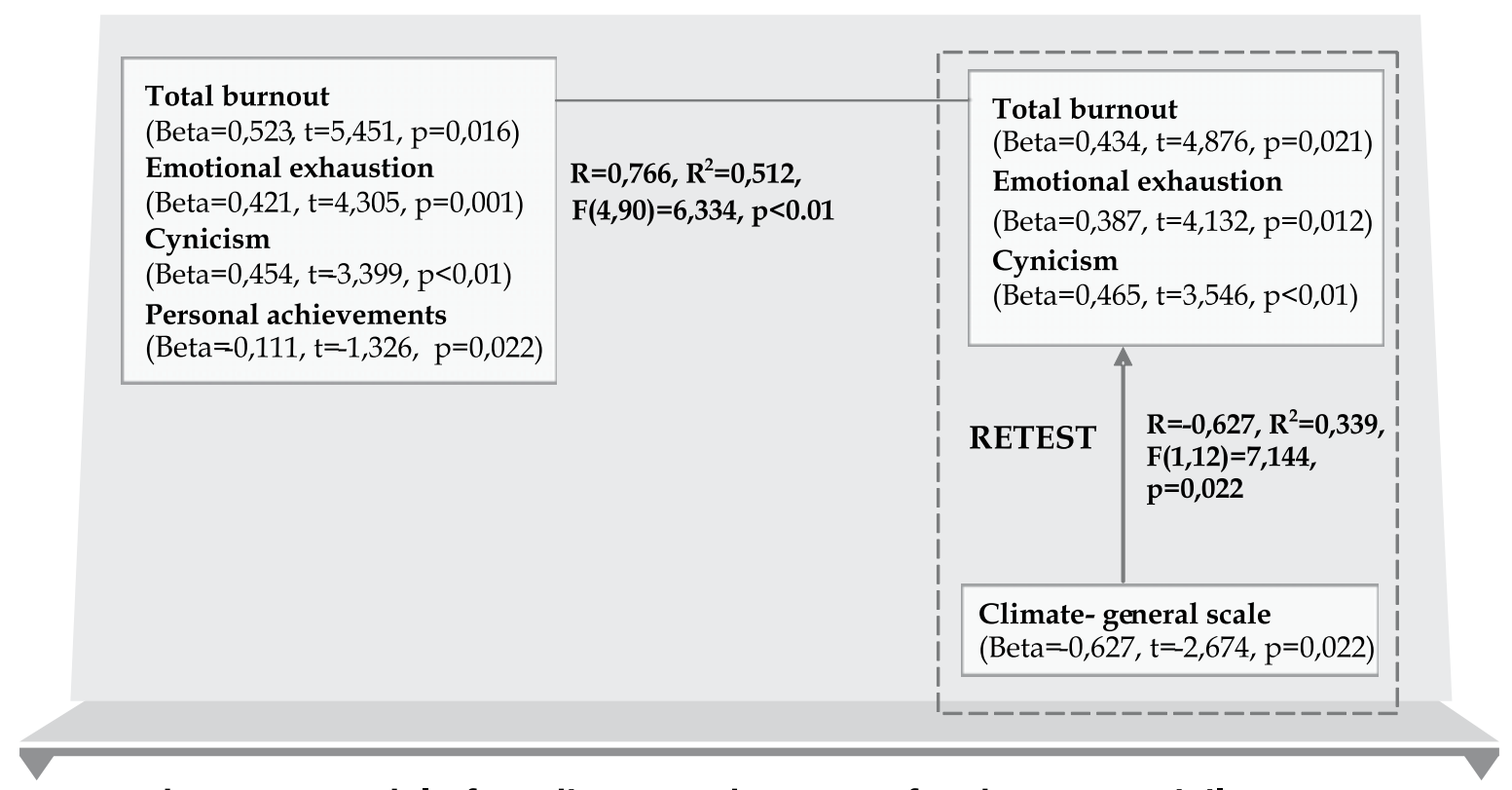

Chart 2. A model of predictors at the re-test for the sector: civil servants

Source: own study 
In case of civil servants, the level of burnout at the re-test is affected by the overall (it can be called "preliminary”) perception of organisational climate (scale: general at the Organisational Climate Questionnaire). This dependency is inversely proportional, namely the more negative organisational perception (lower results in the questionnaire), the higher indicators of professional burnout. However, similarly, as shown in the general model, emotional exhaustion, cynicism and a reduced sense of achievements from the first test mostly affect the development of burnout. This means that in case of the tested people, their average or high results in the scope of exhaustion and cynicism (and quite low in case of a reduced sense of achievements) will impact (with the strength of $\mathrm{R}=0,776$ ) onto the intensification of burnout at the re-test. This dependency is very intense and, as the graph shows, it explains $51 \%$ of the variables: emotional exhaustion, total burnout and cynicism at the re-test.

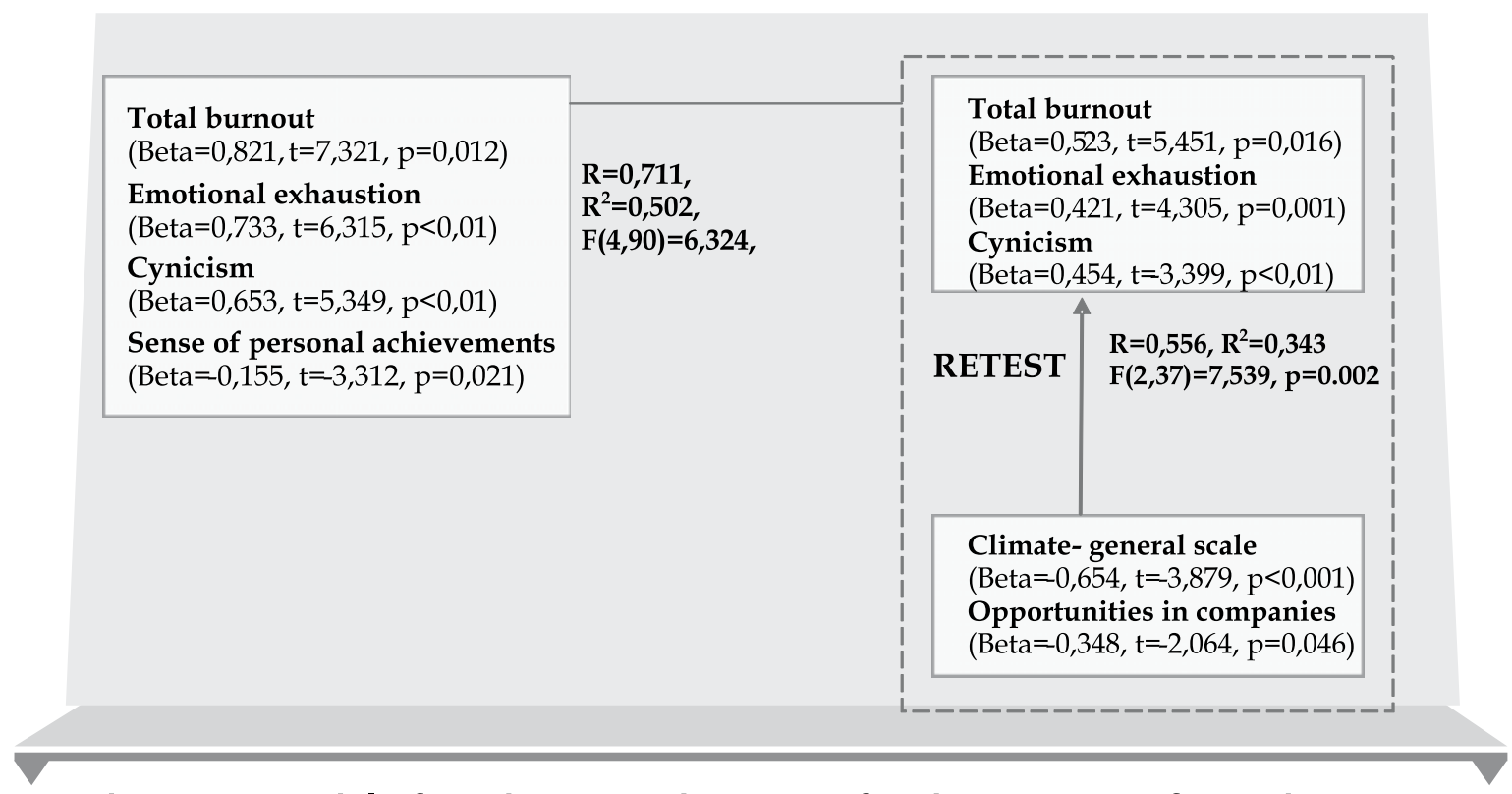

Chart 3. A model of predictors at the re-test for the sector: uniformed services

Source: own study

Armed forces officers (the graph below) is another analysed professional group. Just as in the case of public administration, experiencing the symptoms of burnout in the past affects burnout, exhaustion and cynicism at the re-test most. In the cause-effect model, the dependent variables from the first test explains up 


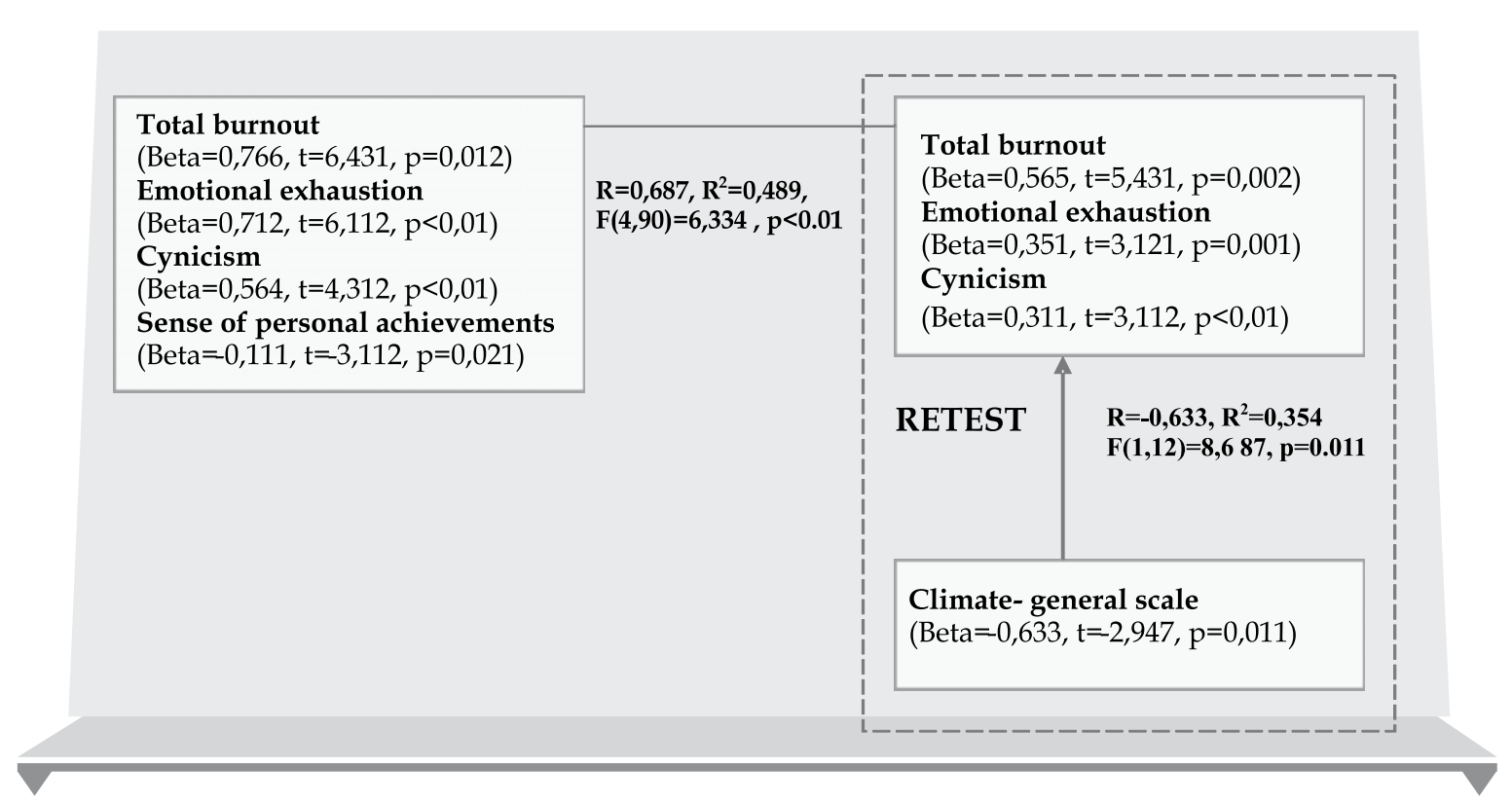

Chart 4. A model of predictors at the re-test for the sector: education

Source: own study

to $50 \%$ of the symptoms of burnout measured at the re-test. Burnout is impacted a little less, but also statistically significantly, by: perception of climate (general assessment) and provision of opportunities for professional development. Both variables are at an inversely proportional relationship with the dependent variables: total burnout, exhaustion and cynicism.

A group of predictors which mostly affect the level of professional burnout and its components at the re-test among people employed in education is presented at another graph.

At the re-test conducted among a group of teachers, the negative general assessment of organisational climate predicts higher emotional exhaustion, cynicism and professional burnout treated as their global result. This variable explains 35\% of the dependent variables which are, however, mostly impacted by the dependent variables (emotional exhaustion, cynicism, a reduced sense of personal achievements) from the first test. Similarly, as in the previous professional sub-groups, experiencing the symptoms of burnout appears to be its most intensive predictor within a long period of time. They explain as much as $48 \%$ of the variability of professional burnout at the re-test. Health care staff is another professional group being subjected to analysis. 


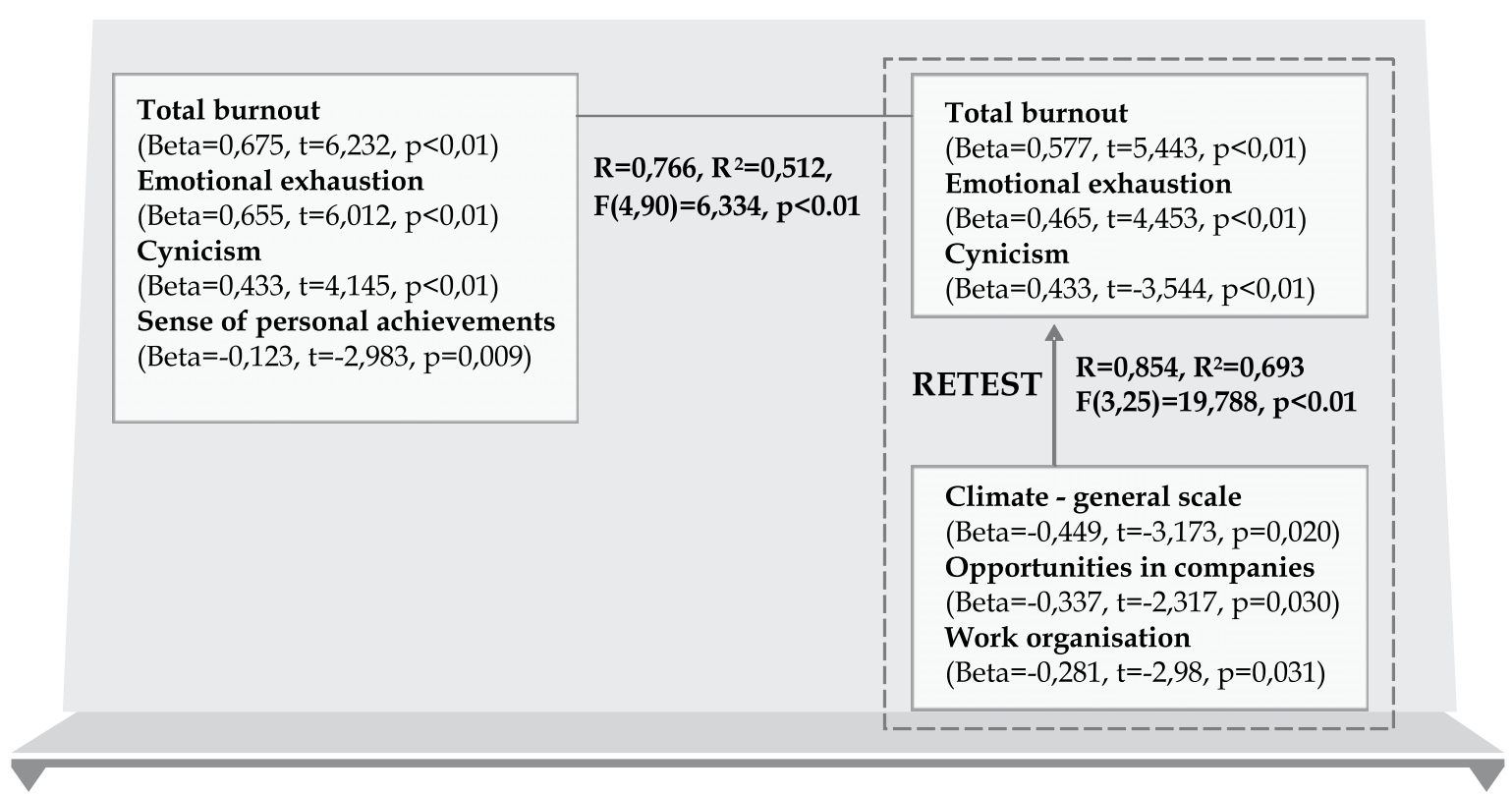

Chart 5. A model of predictors at the re-test for the sector: health care

Source: own study

Health care is the only professional group tested by the authors in which organisational factors (negative general perceptions of organisational climate, no opportunities for development offered by companies and poor organisational work) are at the test more intense predictors of professional burnout than the dependent variables of the first measurement. These predictors explain up to $69 \%$ of the variability of total burnout, emotional exhaustion and cynicism, while the dependent variables of the first measurement affect burnout at the retest with their strength of $R=0,766$ and explain $51 \%$ of the tested phenomenon. Unlike other sectors, deepening of the symptoms of burnout in this group was mostly impacted by organisational factors which during the interval from the first test must have significantly worsened in the perception of people employed.

People employed in the trade and service sector was the last analysed group.

As for people employed in trade and services in the perspective of the nine-month re-test, maintaining and deepening the symptoms of emotional exhaustion, cynicism and burnout treated globally is caused by negative general assessments of the perception of organisational climate $(R=-0,627)$ which explain $33 \%$ of these dependent variables. However, the level of the dependent variables 


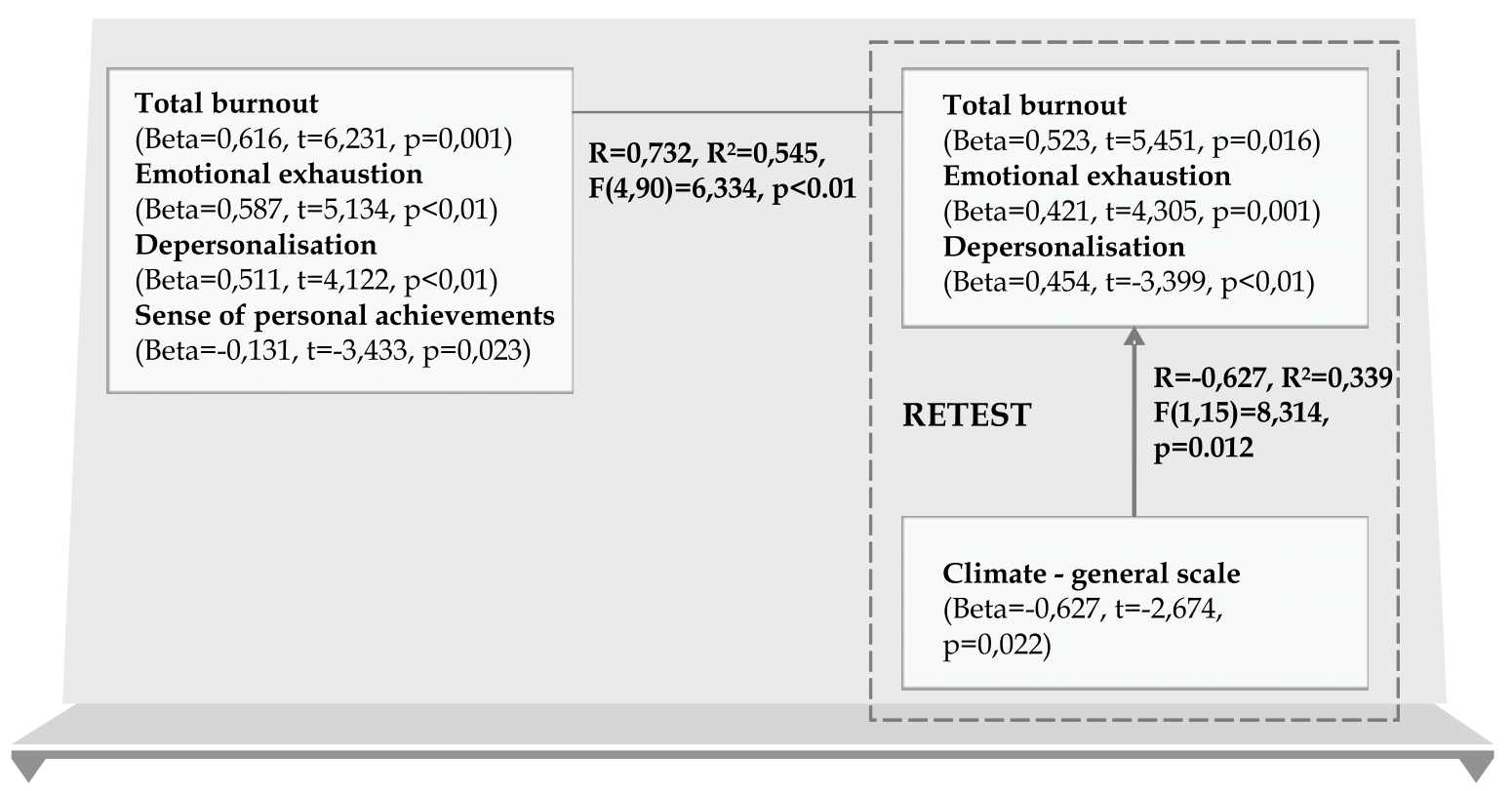

Chart 6. A model of predictors at the re-test for the sector: trade and services

Source: own study

from the first test affected professional burnout more intensely. Particular components of burnout from the first test explain its variability at the re-test up to $54 \%$.

\section{Summary}

The results of the re-test research support the hypothesis on the dynamics of professional burnout. Deepening of the symptoms of burnout applied to people employed in all the tested groups which differ, however, in terms of their predictors and the strength of their impact onto the level of the dependent variables.

On the grounds of the analyses on the result variances obtained in the MBI-GS questionnaire sub-scales it became evident that - upon the nine month interval - the level of cynicism (depersonalisation) significantly increased at the tested people; also burnout intensified globally. No significant changes at the level of emotional exhaustion and a reduced sense of personal achievements were observed. The tested people still assessed themselves as effective professionals. They also assessed their superiors slightly more severely, however the perception 
of managers did not turn out to be a sufficiently significant predictor of burnout in the constructed cause - effect models.

The dependency models built for each of the tested sectors and the common model for all the people employed provided interesting data on burnout and its dynamics. It turned out that the level of exhaustion, cynicism and total burnout at the re-test was mostly impacted the dependent variables from the first test, so the initial levels of exhaustion, cynicism, a reduced sense of achievements and burnout treated globally. Although predictors were sought which account for deepening the process of burnout among all the tested independent variables, the impact made by the dependent variables from the first test was the largest every time and explained about $50-60 \%$ of the variability of burnout at the retest. Only in the health care sector the level of exhaustion, cynicism and burnout at the re-test is mostly affected by organisational factors (general perception of climate, opportunities created at companies, work organisations). In spite of the above, the impact made by the dependent variables from the first test was still high $(\mathrm{R}=0,766)$. They explained up to $51 \%$ of the variability of burnout and its components in the perspective of the nine-month re-test.

Overall, it indicated that developing the symptoms of burnout within its long perspective is mostly affected by "experiences from the past” - previous experiences of burnout. It would indicate a trend of burnout deepening, as it is indeed confirmed by the empirical evidence on the increasing level of cynicism of the tested people. According to some researchers of the phenomenon, this is the exhaustion which is the first symptom of burnout (Maslach, Jackson 1981, Maslach, Leiter 1988, Leiter 1993, Maslach et al. 1996), because it is the fastest form of the body's response to excessive overloading conditions. So far no clear answer has been obtained in relation to the formation of particular symptoms of burnout. The concepts by Golembiewski (1993b), Noworol and Marek (1993) suggest a different, staged course of burnout in which a high level of emotional exhaustion is an extreme, catastrophic stage of burnout and is preceded by fluctuations of cynicism (depersonalisation) and a changeable sense of personal achievements.

The authors of the article made use of the concept of burnout suggested by Maslach and Leiter, therefore their assumptions related to the sequence of the following symptoms: exhaustion, cynicism, a reduced sense of personal achievements were also adopted. Regardless of the theoretical assumptions, the applied neural models prove intense dependencies between and among the dependent variables. It turned out that a sense of personal achievements is not statistically significant in the interactions of exhaustion, exhaustion 
and total burnout at the re-test. For each of the tested occupational groups, the same tendency was observed: very weak dependencies of a sense of personal achievements with other components of burnout at the first test (compare Witkowski, Ślazyk - Sobol, 2012) and no significant dependencies in the perspective of the time interval. This result may prove the weakness of methods measuring a sense of personal achievements. Moreover, according to the researchers, (Maslach et al. 1996; Maslach, Leiter 2008), this construct is the least associated with global burnout. While exhaustion is considered as the main component of burnout, a sense of own professional efficiency is the most independent among all the other components of burnout (Lee \& Ashforth, 1996; Schaufeli and Enzmann 1998). In the literature on the subject there are also propositions of the two-factor model of professional burnout based on exhaustion and cynicism only (Green, Walkey, Taylor 1991) omitting professional achievements as a factor loading the construct called "organisational commitment" rather than professional burnout (Schaufeli 2008). With regard to the concept of Maslach and Leiter no personal satisfaction derived from work is the result of long-lasting processes of exhaustion and cynicism, so it should occur at the latest, especially in the group of extremely burned people. Maybe the tested groups have not experienced this stage of burnout yet, which caused that exhaustion and cynicism turned out to be the key symptoms of burnout at the re-test. However, according to the authors, a discussion on a reduced sense of achievement should be undertaken. It is worth considering if - under the operation of Polish organisations - it is reasonable to include a sense of personal achievements to the components of burnout and to launch longitudinal studies to verify the possible dynamics of this construct.

The applicable conclusions resulted from the conducted research relate primarily to the prophylaxis of burnout and preventive measures which could alleviate the symptoms of the phenomenon. With regard to the presented dependency models, it should be stressed once again that deepening the dynamics of burnout at the time perspective is mostly impacted by experiencing its symptoms in the past. As shown by the research presented in the present paper, burnout tends to deepen in the course of time.

The presented results raise a lot of questions about the consequences of the state and further deepening of its symptoms. Concerns include whether an employed person "trapped" by burnout is inevitably doomed to experience its extreme symptoms and their consequences, or maybe there is chance for "treatment" and effective psychological and organisational intervention? 
It is not known whether - as suggested by Cherniss (1992) at his research on re-tests conducted after several years - people who are affected by burnout can be "spontaneously" treated, based on their resources invested in vocational training. The opinion of Miller and Smith (1997) suggests that a person - in spite of experiencing burnout - has sufficient energy reserves to recover and regenerate. He / she can undertake actions with verve and vigour. This approach describes the extreme experience of burnout as the phenomenon of the Phoenix reborn from the ashes. However, there is no empirical evidence to support this hypothesis. To prove it true, it should show the moment at the spiral of burnout at which the person begins to "recover" his / her resources.

Due to the significant increase in cynicism at the re-test, it is worth considering to build personal development programs such as individual coaching based on the strengthening of personal resources. Also psychosocial skills workshops aimed at the creation of attitudes of co-operation and openness at staff teams could "weaken" distrust and distance of employed people experiencing burnout and above all encourage them to seek support and assistance in organisations.

As it is concluded from the above charts, the general perception of organisational climate, work organisation and creating opportunities for professional development are the strongest and the most universal organisational predictors of burnout at the re-test. It would seem that adequate support of superiors to satisfy the needs of their subordinates in these areas could contribute to the reduction of acute consequences of professional burnout among people employed. Of course, as the research shows, these actions are not sufficient for proper prevention because above all first symptoms of the phenomenon should be prevented as they tend to significantly escalate in the long term. There is no doubt that in order to "capture" professional burnout, it is required - according to the authors - to conduct further longitudinal studies on the issues presented.

\section{Summary}

Dynamics of professional burnout - a comparative analysis considering the key sectors in Poland, part II

The article is a continuation of the study presented in the text entitled: "Professional burnout - a comparative analysis considering the selected sectors in Poland". Management. University of Zielona Góra, Faculty of Economics and Management, Vol.16, No.2., (p. 87 - 102). 
The authors present the results of the second part of the research on analysing the phenomenon of burnout among employees of the major sectors in Poland. The present material relates to the results of the re-test conducted after the nine-month interval. One again the cause-effect dependency models for the verified variables were presented for all the tested employed people and separately for each of the specified sectors. The most relevant applicable conclusions resulted from the implemented research projected were formulated.

Keywords: dynamics of professional burnout, cynicism, emotional exhaustion, reduced sense of achievements, organisational climate.

\section{Streszczenie}

Dynamika wypalenia zawodowego - analiza porównawcza z uwzględnieniem głównych branż w Polsce, część II

Artykuł stanowi kontynuację pracy przedstawionej w tekście "Professional burnout - a comparative analysis considering the selected sectors in Poland". Management. Universtity of Zielona Góra, Faculty of Economics and Management, Vol. 16, No.2., (p. 87 - 102). Autorzy prezentują wyniki drugiej części badań poświęconych analizie zjawiska wypalenia wśród pracowników głównych branż w Polsce. Niniejszy materiał dotyczy wyników retestu, zrealizowanego po dziewięciomiesięcznej przerwie. Ponownie przedstawiono modele zależności przyczynowo skutkowych dla weryfikowanych zmiennych w odniesieniu do wszystkich badanych pracowników a także oddzielnie dla każdej z opisywanych branż. Sformułowano także najważniejsze wnioski aplikacyjne wynikające ze zrealizowanego projektu badawczego.

\section{Słowa}

kluczowe: dynamika wypalenia zawodowego, cynizm, wyczerpanie emocjonalne, obniżone poczucie osiagnięć, klimat organizacyjny.

\section{References}

1. Augustynowicz P. (1997), Adaptacja kulturowa kwestionariusza do badania klimatu organizacyjnego. Niepublikowana praca magisterska pod kierunkiem prof. UWr. dr. hab. Stanisława A. Witkowskiego. 
2. Cherniss C. (1992), Long - term consequences of burnout. An exploratory study. Journal of organizational behaviour. Vol. 13, (p. 1-11).

3. Cherniss C. (1993), Role of Professional self - efficacy In the etiology and ameliorationof burn - out, in: Schaufeli W.B., Maslach C., Marek T. (eds.).Proffessional Burnout: Recent Developments in Theory and Research, (p. 135-149). Washingotn, DC: Tylor \& Francis.

4. Cherniss C. (1995), Beyond burnout: Heliping teachers, nurses, therapists and lawyers recover from stress and disillusionment. New York: Routledge.

5. Green, D.E., Walkey, F.H., Taylor, A.J.W. (1991), The three-factor structure of the Maslach Burnout Inventory. Journal of Science Behavior and Personality, 6, (p. 453-472).

6. Golembiewski R.T., Scherb K, Boudreau R.A. (1993a), Burnout in cross - national sttings. Generic and model - specific perspectives, in: Schaufeli W.B., Maslach C., Marek T. (eds.).Proffessional Burnout: Recent Developments in Theory and Research, (p. 217-236. Washingotn, DC: Tylor \& Francis.

7. Golembiewski R.T. Boudreau R.A., Goto K., Murai T. (1993b), Transnational perspectives on job burnout: replication of phase model results among Japanese respondents. The International Journal of Organizational Analysis. Vol. 1, No. 1, (p. 7-27).

8. Lee, R.T., \& Ashforth, B.E. (1996), A meta-analytic examination of the correlates of the three dimensions of job burnout. Journal of Applied Psychology, 81, p. 123-133.

9. Masach Ch., Jackson S. (1981), The measurment of experienced burnout. Journal of Occupational Behaviuor. Vol. 2, (p. 99-113).

10. Maslach Ch., Jackson S.E, Leiter M. (1996), MBI Manual. 3rd ed. Mountain View, CA:CPP, Inc.

11. Maslach Ch. (1998). A Multidimensional Theory of Burnout, in: Cooper C.L. (ED.). Theories of organizational stress, (p. 68-85). New York: Oxford University Press.

12. Maslach Ch, Leiter M.P. (2008), Early predictors of Job burnout and engagement. Journal of Applied Psychology. Vol., 93, No. 3, (p. 498-512).

13. Maslach Ch., Leiter M.P. (2010), Pokonać wypalenie zawodowe. Sześć strategii poprawiania relacji z praca. Warszawa: Oficyna Wolters Kluwer business.

14. Maslach Ch., Leiter M.P. (2011), Prawda o wypaleniu zawodowym. Co robić ze stresem w organizacji. Warszawa: Wydawnictwo Naukowe PWN.

15. Miller L.H., Dell Smith A. (1999), The road to burnout, the stress solution (online), American Psychological Association, http://library.thinquest. org/255500/stres/references/htm.

16. Noworol Cz., Marek T. (1993), Typology of burnout, methodology of the modelling of the syndrome. Polish Psychological Bulletin, Volume 24, Number 4, (p. 319-326). 
17. Schaufeli W.B., Enzmann D. (1998), The burnout companion to study and practise: A Critical Analysis. London: Taylor and Francis.

18. Schaufeli W.B., Taris T.W., Rhenen W. (2008), Workaholism, Burnout and work engagement: three of a kind or three different kinds of employee well - being. Applied Psychology: an international review, 57, (p. 173-203).

19. Ślazyk - Sobol M. (2012), Podmiotowe i organizacyjne uwarunkowania zjawiska wypalenia zawodowego. Niepublikowana rozprawa doktorska pod kierunkiem prof. dr hab. Stanisława A. Witkowskiego.

20. Witkowski S.A., Ślazyk - Sobol M. (2012), Professional burnout a comparative analysis considering the selected sectors in Poland. Management. Universtity of Zielona Góra, Faculty of Economics and Management, Vol. 16, No. 2., (p. 87-102). 